\title{
EFFECT OF POTASH ADDITION ON GROUNDNUT OIL YIELD AND QUALITY OF KULIKULI (FRIED GROUNDNUT CAKE)
}

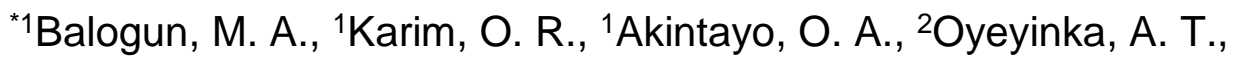 \\ ${ }^{1}$ Kolawole, F.L. and ${ }^{1}$ Okereke, E. E. \\ 1'Department of Home Economics and Food Science, University of Ilorin, \\ Nigeria \\ ${ }^{2}$ Department of Food Science and Technology, Kwara State University, \\ Malete, Nigeria \\ *Corresponding Author: bmutiatadebanke@yahoo.com
}

\begin{abstract}
Fried groundnut cake, popularly called kulikuli, is obtained by frying the cake obtained from groundnut oil extraction. Addition of potash during defatting of groundnut is believed to increase oil yield and improve kulikuli quality, but there is little or no scientific information explaining this. This study investigated the yield, physical and chemical properties of oil extracted from groundnut with the addition of potash at $0.16,0.32,0.48$ and $0.64 \%$. The proximate and sensory attributes of the kulikuli produced were also determined. Groundnut yield increased from $14 \%$ to $27 \%$ with increasing addition of potash, presumably due to the emulsifying properties of potash. Potash addition significantly $(p<0.05)$ influenced the refractive indices, percentage impurity and colour of the oil samples. Oil extracted without potash had the lowest iodine value $(85.12 \mathrm{mg} / 100 \mathrm{~g})$, saponification value $(202.2 \mathrm{mg} \mathrm{KOH} / \mathrm{g})$, acid value $(6.46 \mathrm{mgKOH} / \mathrm{g})$ and peroxide value $(5.66 \mathrm{meq} / \mathrm{Kg})$. The kulikuli had moisture in the range of $1.45-3.00 \%$; carbohydrate, $20.6-40.4 \%$; protein, 30.5 - 40.8\%; ash, 4.45 - 5.05\%; and fat, 23.5 - 30.6\%. Kulikuli sample without potash was the most preferred based on taste and aroma while sample with $0.64 \%$ potash was the most preferred based on crunchiness, colour, breakability and overall acceptability. The study confirmed the hypothesis that potash addition during extraction of oil and production of kulikuli increases oil yield and some of the quality attributes of the kulikuli.
\end{abstract}

Keywords: Groundnut, potash, oil yield, kulikuli, quality attributes 


\section{INTRODUCTION}

Groundnut (Arachis hypogeal) is one of the most important leguminous crops in Nigeria and other tropical countries. It is rich in protein (22-30\%), oil (3556\%) (Zekeri and Tijjani, 2013; Gulluoglu et al., 2016) and contains appreciable amounts of minerals (Phosphorus, Calcium, Magnesium and Potassium) and vitamins (E, K and B) (Gulluoglu et al., 2016). Groundnut may be consumed in various forms (Osei et al., 2013; Ibrahim et al., 2017), for example, it can be consumed raw or processed into a paste used as a spread for baked goods and the oil used for cooking. A popular product from groundnut in Nigeria is kulikuli, a snack produced by frying the residue obtained from groundnut oil extraction. Furthermore, the nut has various industrial uses including products such as food, feed, paints, lubricants and as insecticides (Variath and Janila, 2017).

Groundnut oil has enormous potentials for industrial applications because it has a similar smoke point of $225^{\circ} \mathrm{C}$ (Sarwar et al., 2016) compared to that of soybean oil $(229 \stackrel{\circ}{\circ})$ (Syed et al., 2019). The relatively high smoke point of groundnut oil suggests that it is suitable for high temperature cooking (Sarwar et al., 2016). In addition, groundnut oil is reported to contain glycerides with significant amounts of unsaturated fatty acids such as oleic (35-61\%) and linoleic (16-4\%) (Yol et al., 2017). The high oil content of groundnut and the good physicochemical properties, as indicated above, makes groundnut oil extraction very valuable and commercially viable. A preliminary investigation by our research team revealed that for optimized oil yield, processors adopt certain practices. One of such is the use of potash, which is traditionally believed to enhance oil extraction when added to groundnut.

Potash which is also known as akanwu in Igbo, kanwa in Hasua and kaun by the yorubas is a dry lake-salt with water of crystallization $\left(\mathrm{Na}_{2} \mathrm{CO}_{3} \mathrm{NaHCO}_{3} .2 \mathrm{H}_{2} \mathrm{O}\right)$. It is an alkaline salt that is a mixture of different substances. Though, with little or no scientific proof, it is traditionally believed in Nigeria that potash addition during extraction of groundnut oil increases the oil yield and the quality of kulkuli obtained. Therefore, the aim of this study was to investigate the effect of addition of potash on the yield and quality of groundnut oil and the sensory attributes of kulikuli.

\section{MATERIALS AND METHODS \\ Materials}

The groundnut, potash, onions and pepper used in this study were obtained from Oja Oba market in llorin, Kwara State, Nigeria. 


\section{Extraction of Groundnut Oil and Production of Kulikuli from Groundnut}

The groundnut was sorted to remove damaged and unwholesome seeds, as well as stones. The cleaned seeds were roasted for about $20 \mathrm{~min}$ at a temperature of $180^{\circ} \mathrm{C}$ in an oven. It was then allowed to cool after which it was dehulled and milled. The milled groundnut was then mixed with potash at the concentrations of $0.16 \%, 0.32 \%, 0.48 \%$ and $0.64 \%$. The various groundnutpotash mixtures were expressed by oil expeller to extract oil. The groundnut cakes obtained after oil extraction were then fried to produce kulikuli (Ayoade and Adegbite, 2016).

\section{Colour Determination of Groundnut Oil}

The colour of the groundnut oil samples was determined using a tristimulus chroma meter (CR-310, Minolta Camera Co. Ltd., Osaka, Japan). Prior to colour measurement, the chroma meter was calibrated using a white Minolta calibration plate No. 14333116. Groundnut oil samples were filled into a cleandried glass petri dish and covered with the lid. $L^{*} a^{*} b^{*}$ colour determination was done by taking measurements on three different parts of the lid covering the groundnut oil samples. The analyses were done in triplicates.

\section{Determination of Physical Properties}

Percentage impurity was determined following the procedure previously described by Opoku-Boahen et al., (2013). Refractive index was determined using a hand-held digital refractometer (Model: ATAGO® Digital Branch Refractometer RX-5000i-Plus).

\section{Determination of Chemical Properties}

Percentage acid, peroxide, iodine, and saponification values were determined using the method of the American Oil Chemists' Society (1993).

\section{Proximate Analysis}

The moisture, ash, protein, crude fibre and crude lipid contents were determined using the method of AOAC (2005) while the carbohydrate contents were determined by difference.

\section{Sensory Evaluation of Kulikuli}

Sensory evaluation was carried out on the kulikuli samples produced from resulting groundnut residues after oil extraction. The parameters analysed were appearance, aroma, taste, texture, and overall acceptability. This was done on a 9-point hedonic scale of preference where 1 and 9 represent 'dislike extremely' and 'like extremely', respectively. Fifty panelists, who are familiar with the quality attributes of kulikuli, were selected from among students and staff of the Department of Home Economics and Food Science, University of 
Ilorin, Ilorin, Kwara State. Prior to the sensory evaluation, the panelists were screened based on their interest to participate.

\section{Statistical Analysis}

Data obtained from the analyses above were subjected to analyses of variance (ANOVA), and means were separated by Duncan test, using Statistical Software for Social Science (SPSS), Version 16.0.

\section{RESULTS AND DISCUSSION}

\section{Yields of Groundnut Oil Extracted with Potash}

Potash addition significantly increased the oil yield (14-27\%) from groundnut. Oil extracted without potash gave lower yield compared to oil samples extracted with potash. With increase in the addition of potash, the oil yield progressively increased. This can be attributed to the emulsifying property of potash. Water is usually used to extract oil from groundnut; the emulsification helps the water to bind more effectively since there is a limit to which water can extract oil from groundnut due to polarity difference.

\section{Physical Properties of Groundnut Oil Extracted with Potash}

The $b^{*}$ value for colour which indicates yellowness appeared to be significantly different $(p<0.05)$ for the various groundnut oil samples (Table 1$)$. The oil samples were generally yellow from the result obtained and were similar to the values (20-25) reported by Shahidi (2005). However, the $b^{*}$ value appeared to decrease with potash addition. The lowest $b^{*}$ value reported for oil extracted with the highest potash concentration suggests that potash addition during extraction had negative implication on the expected colour of groundnut oil. This can reduce the attractiveness of this oil and limit its commercial potential.

Visually, there were significant $(p<0.05)$ differences in the refractive indices of the groundnut oil samples (Table 1). The values increased with increase in the addition of potash. This showed that light travels more slowly through the oil samples with increasing addition of potash. Oil extracted with $0.64 \%$ potash gave the highest value (1.47) while that extracted without potash gave the least value (1.36). Oil extracted without potash had a value similar to what was reported by Shahidi (2005). The result showed that addition of potash increased the value of refractive index indicating the presence of impurities. This indicates that oil extracted with potash is less pure. Refractive index is usually used as a criterion for oil purity. The more the soluble substances in oil, the greater the bend or refraction of light through it.

The percentage impurity is a measure of the amount of foreign substances such as hulls from the groundnut and sand particles in fats and oils (Dimic et 
al., 2012). The percentage impurity values ranged between 0.25 and $0.44 \%$. Sample extracted without potash had the least foreign material content $(0.25 \%)$ while that extracted with $0.64 \%$ of potash had comparatively the highest (Table 1). This indicates that potash addition during extraction reduced the quality of oil produced. Dimic et al., (2012) showed that impurities have a negative effect on sensory characteristics such as the taste and odour as well as the chemical quality of oil samples. The presence of impurities also affects colour of the oil samples, giving them a turbid appearance (Dimic et al., 2012).

Table 1. Physical properties of groundnut oil extracted with potash.

\begin{tabular}{cccc}
\hline $\begin{array}{c}\text { Potash } \\
\text { concentration (\%) }\end{array}$ & $\begin{array}{c}\text { Refractive index } \\
@ 25^{\circ} \mathrm{C}(\mathrm{nD})\end{array}$ & \% Impurity & $\begin{array}{c}\mathrm{b}^{*} \text { (yellowness } \\
\text { index) }\end{array}$ \\
\hline 0 & $1.36^{\mathrm{d}} \pm 0.01$ & $0.25^{\mathrm{e}} \pm 0.01$ & $+24.49^{\mathrm{a}} \pm 0.05$ \\
0.16 & $1.36^{\mathrm{d}} \pm 0.01$ & $0.32^{\mathrm{d}} \pm 0.00$ & $+23.37^{\mathrm{b}} \pm 0.03$ \\
0.32 & $1.37^{\mathrm{c}} \pm 0.00$ & $0.38^{\mathrm{c}} \pm 0.00$ & $+22.45^{\mathrm{c}} \pm 0.05$ \\
0.48 & $1.39^{\mathrm{b}} \pm 0.00$ & $0.41^{\mathrm{b}} \pm 0.01$ & $+20.47^{\mathrm{d}} \pm 0.02$ \\
0.64 & $1.47^{\mathrm{a}} \pm 0.00$ & $0.44^{\mathrm{a}} \pm 0.01$ & $+19.48^{\mathrm{e}} \pm 0.04$ \\
\hline
\end{tabular}

Values are means $(n=2) \pm S$. $D$; mean values down the column with the same superscripts are not significantly $(P \geq 0.05)$ different.

\section{Chemical Properties of Groundnut Oil Extracted with Potash}

The iodine values ranged between 85.1 and $88.3 \mathrm{~g} / 100 \mathrm{~g}$. 107.24. These values are within the range reported for hazelnut seed oil (86.79-89.40 g/100 g) (Uquiche et al., 2008) and raw (107.24 g/100 g) and gamma-irradiated (104.08-116.76 g/100 g) groundnut oil (Al-Bachir, 2015). lodine value is an indication of the quality of unsaturated fatty acids present in a fat and has been used to predict the shelf life of the fat and oil. In this study, iodine value of the groundnut oil increased with increasing levels of potash. The sample extracted with $0.64 \%$ potash had the highest iodine value, indicating a higher degree of unsaturation. The reason for this is not clear and may be a subject for further investigation.

The saponification values of the oil samples ranged between 202.2 and 224.6 $\mathrm{mg} \mathrm{KOH} / \mathrm{g}$. The saponification values obtained were similar to the range (198.1-220.20 mg KOH/g) reported by Nkafamiya et al., (2010). Akinhanmi et al., (2008) reported that saponification value of groundnut oil falls within the range of $188-196 \mathrm{mg} \mathrm{KOH} / \mathrm{g}$ oil. Al-Bachir (2015) reported that saponification value is used in checking the level of adulteration in oils. High saponification value is associated with high molecular weight fatty acids and low level of impurities. Potash addition to the groundnut prior to extraction significantly increased the saponification value of the oil. The relatively high saponification 
value of the groundnut oil in this study is an evidence that the extracted oil could be used in soap making industry (Bhatti et al., 2010).

The acid values of the groundnut oil samples were significantly different (Table 2). Sample extracted with $0.64 \%$ of potash had the highest amount of acid value $(10.66 \mathrm{mgKOH} / \mathrm{g})$ and sample extracted without potash had the least $(6.46 \mathrm{mgKOH} / \mathrm{g})$. The acid value measures the degree at which lipase breaks down glycerides in the oil and indicates the amount of free fatty acid present in the oil (Al-Bachir 2015). Furthermore, the acid value is also useful in determining the level of hydrolytic and lipolytic activities in the oil. Al-Bachir (2015) reported very low acid value $(1.78 \mathrm{mgKOH} / \mathrm{g})$ for groundnut oil compared to values $(6.46-10.66 \mathrm{mgKOH} / \mathrm{g})$ obtained in this study. The variation in the acid value may be due to the source of the groundnut, processing method and the degree of refining to which the oil is subjected to. The acid values of the oil samples in this study increased with increase in the addition of potash indicating that potash possibly enhanced the lipolysis of the oil, resulting to the release of freer fatty acids. Therefore, groundnut oil extracted using potash may require refining prior to use especially for industrial applications.

The peroxide values obtained for the oil samples were between 5.66 and $12.24 \mathrm{mEq} / \mathrm{kg}$ (Table 2). There were significant differences $(p<0.05)$ among the samples. The lowest peroxide value was recorded for sample extracted without potash while sample extracted with $0.64 \%$ potash recorded the highest value. The quantity of peroxides found in an oil or fat is an indication of the level of oxidation (Syed et al., 2019). Peroxides are the cause of rancidity in oil and are primary compounds formed by the oxidation of unsaturated fatty acids (Syed et al., 2019; Gomathi et al., 2011). The peroxide value results show that the sample extracted without potash would have longer shelf life and those extracted with potash may require higher level of antioxidants to further prevent oxidation during storage.

Table 2. Chemical properties of groundnut oil extracted with potash

\begin{tabular}{lllll}
\hline $\begin{array}{l}\text { Potash } \\
\text { concentration } \\
(\%)\end{array}$ & $\begin{array}{l}\text { lodine value } \\
(\mathrm{g} / 100 \mathrm{~g})\end{array}$ & $\begin{array}{l}\text { Saponification } \\
\text { value } \\
(\mathrm{mgKOH} / \mathrm{g})\end{array}$ & $\begin{array}{l}\text { Acid value } \\
(\mathrm{mgKOH} / \mathrm{g})\end{array}$ & $\begin{array}{l}\text { Peroxide } \\
\text { value } \\
(\mathrm{meg} / \mathrm{Kg})\end{array}$ \\
\hline 0 & $85.12^{\mathrm{c}} \pm 0.01$ & $202.2^{\mathrm{e}} \pm 0.03$ & $6.46^{\mathrm{e}} \pm 0.04$ & $5.66^{\mathrm{c}} \pm 0.05$ \\
0.16 & $85.16^{\mathrm{c}} \pm 0.00$ & $223.7^{\mathrm{d}} \pm 0.04$ & $6.68^{\mathrm{d}} \pm 0.04$ & $5.66^{\mathrm{c}} \pm 0.05$ \\
0.32 & $85.22^{\mathrm{c}} \pm 0.03$ & $224.0^{\mathrm{c}} \pm 0.01$ & $9.50^{\mathrm{c}} \pm 0.07$ & $10.03^{\mathrm{b}} \pm 0.04$ \\
0.48 & $87.16^{\mathrm{b}} \pm 0.03$ & $224.2^{\mathrm{b}} \pm 0.03$ & $10.02^{\mathrm{b}} \pm 0.06$ & $12.19^{\mathrm{a}} \pm 0.04$ \\
0.64 & $88.30^{\mathrm{a}} \pm 0.03$ & $224.6^{\mathrm{a}} \pm 0.12$ & $10.66^{\mathrm{a}} \pm 0.04$ & $12.24^{\mathrm{a}} \pm 0.00$ \\
\hline
\end{tabular}

Value are means $(n=2) \pm$ S.D mean values down the column with the same superscripts are not significantly different $(P \geq 0.05)$. 


\section{Chemical Composition of Kulikuli Produced from Groundnut Cake after Oil Extraction with Potash}

The moisture contents of the kulikuli samples were generally very low and ranged between 1.45 and $3.00 \%$ (Table 3). There were significant differences in the moisture content of the different kulikuli samples. The highest moisture content was recorded in sample extracted without potash while the lowest moisture content was recorded in sample extracted with $0.64 \%$ potash. The results are within the values reported by Emelike and Akusu (2018) on addition of cashew kernel to groundnut to produce kulikuli. Ezekiel et al., (2011) reported moisture values ranging from $1.5 \%$ to $5.0 \%$.

The protein values obtained were within the range of $30.49 \%$ and $40.75 \%$ for the kulikuli samples (Table 3). The protein contents of the kulikuli samples were within reported range of $26.4 \%$ to $39.7 \%$ (Ezekiel et al., 2011). Groundnut proteins contribute significantly to the development of the nutty flavours and colour formation through Maillard reactions during roasting of peanuts (Grosso et al., 2008). The values decreased with increase in addition of potash which shows that potash addition affects the protein value. The amount of ash remaining after the combustion of biological substances is often used as the measure of the mineral content of the substance (Belitz et al., 2009). The total ash content determined for the kulikuli samples differed significantly $(p<0.05)$ (Table 3$)$. Ash contents ranged from 4.45 to $5.05 \%$. Sample extracted without potash had the least value while that extracted with $0.64 \%$ had the highest value. The result obtained from sample without potash is similar to the value reported by Ezekiel et al., (2011). Potash addition increased the amount of inorganic substances in the oil samples.

The fat contents of the kulikuli samples were significantly different $(p<0.05)$ (Table 3). Fat contents decreased with increasing amount of potash. The fat levels were within the range of $21.95-30.60 \%$ for kulikuli samples in Nigerian markets (Ezekiel et al., 2011). The level of fats indicates the low recoveries of fats in the cake as well as fat reabsorbed by the cake during the frying process. Fats are the predominant constituents of groundnuts and its products. This makes them an invaluable source of dietary energy for consumers. They also play an important role in achieving the texture, mouth-feel and aroma of many peanut products (Mazaheri-Tehrani et al., 2009).

The carbohydrate contents of kulkuli samples ranged from the lowest $(20.60 \%)$ for sample extracted without potash to the highest $(40.35 \%)$ for sample extracted with $0.64 \%$ of potash (Table 3$)$. Significant variation ( $p<$ 0.05 ) in carbohydrate contents were observed among the samples of kulkuli. The result shows that as addition of potash increases, the carbohydrate 
content increased which indicated that potash had effect on the carbohydrate content.

Table 3. Proximate properties of kulikuli produced from groundnut cake after oil extraction with potash.

\begin{tabular}{llllll}
\hline $\begin{array}{l}\text { Potash } \\
\text { concentration } \\
(\%)\end{array}$ & $\begin{array}{l}\text { Moisture } \\
(\%)\end{array}$ & $\begin{array}{l}\text { Crude } \\
\text { Protein }(\%)\end{array}$ & $\begin{array}{l}\text { Ash } \\
(\%)\end{array}$ & $\begin{array}{l}\text { Fat } \\
(\%)\end{array}$ & $\begin{array}{l}\text { Carbohydrate } \\
(\%)\end{array}$ \\
\hline 0 & $3.00^{\mathrm{a}} \pm 0.01$ & $40.75^{\mathrm{a}} \pm 0.07$ & $4.45^{\mathrm{a}} \pm 0.00$ & $30.60^{\mathrm{a}} \pm 0.14$ & $21.20^{\mathrm{a}} \pm 0.14$ \\
0.16 & $2.36^{\mathrm{b}} \pm 0.04$ & $37.15^{\mathrm{b}} \pm 0.07$ & $4.70^{\mathrm{b}} \pm 0.00$ & $29.30^{\mathrm{b}} \pm 0.00$ & $26.49^{\mathrm{d}} \pm 0.14$ \\
0.32 & $2.03^{\mathrm{c}} \pm 0.00$ & $36.10^{\mathrm{c}} \pm 0.28$ & $4.80^{\mathrm{b}} \pm 0.00$ & $27.20^{\mathrm{c}} \pm 0.14$ & $29.87^{\mathrm{c}} \pm 0.42$ \\
0.48 & $1.77^{\mathrm{d}} \pm 0.00$ & $33.20^{\mathrm{d}} \pm 0.14$ & $4.90^{\mathrm{c}} \pm 0.00$ & $25.90^{\mathrm{d}} \pm 0.00$ & $34.32^{\mathrm{b}} \pm 0.14$ \\
0.64 & $1.45^{\mathrm{a}} \pm 0.01$ & $30.49^{\mathrm{a}} \pm 0.21$ & $5.05^{\mathrm{d}} \pm 0.71$ & $23.50^{\mathrm{a}} \pm 0.14$ & $39.51^{\mathrm{a}} \pm 0.21$ \\
\hline
\end{tabular}

Value are means $(n=2) \pm S$.D mean values down the column with the same superscripts are not significantly different $(P \geq 0.05)$.

\section{Sensory Qualities of Kulikuli Produced from Groundnut Cake after Oil Extraction with Potash.}

The results of the sensory evaluation (Table 4) showed that kulikuli sample produced without potash was significantly better in terms of aroma and taste than other samples. However, samples with potash were also generally accepted. The crunchiness and breakability of kulikuli without potash were least rated by the panelist, suggesting the positive effects of potash on these attributes. This plausibility appears supported by the highest ratings of crunchiness and breakability recorded with higher amount of potash. This particular sample was also most preferred in overall acceptability suggesting that crunchiness and breakability are vital sensory properties which influence the choice of consumers. In terms of appearance there was no significant $(p<0.05)$ difference among the samples and this implies that the addition of potash had no effect on the appearance of the kulkuli samples.

Table 4. Sensory evaluation of kulikuli produced from groundnut cake after oil extraction with potash.

\begin{tabular}{lllllll}
\hline Sample & Aroma & Appearance & Taste & Breakability & Crunchiness & $\begin{array}{l}\text { Overall } \\
\text { acceptability }\end{array}$ \\
\hline KPO & $7.64^{\mathrm{a}} \pm 1.19$ & $7.46^{\mathrm{a}} \pm 1.31$ & $7.52^{\mathrm{a}} \pm 1.37$ & $5.78^{\mathrm{c}} \pm 1.86$ & $5.84^{\mathrm{c}} \pm 1.85$ & $7.14^{\mathrm{b}} \pm 1.49$ \\
KPP & $6.68^{\mathrm{b}} \pm 1.44$ & $7.18^{\mathrm{a}} \pm 1.32$ & $6.74^{\mathrm{b}} \pm 1.23$ & $6.52^{\mathrm{b}} \pm 1.75$ & $6.20^{\mathrm{b}} \pm 1.54$ & $6.90^{\mathrm{b}} \pm 1.04$ \\
KPQ & $6.98^{\mathrm{b}} \pm 1.38$ & $7.18^{\mathrm{a}} \pm 1.32$ & $6.80^{\mathrm{b}} \pm 1.34$ & $6.88^{\mathrm{b}} \pm 1.60$ & $6.94^{\mathrm{a}} \pm 1.63$ & $7.24^{\mathrm{b}} \pm 1.21$ \\
KPR & $6.42^{\mathrm{b}} \pm 1.44$ & $7.10^{\mathrm{a}} \pm 1.20$ & $6.50^{\mathrm{b}} \pm 1.25$ & $6.72^{\mathrm{b}} \pm 1.59$ & $6.76^{\mathrm{ab}} \pm 1.62$ & $7.08^{\mathrm{b}} \pm 1.16$ \\
KPS & $6.86^{\mathrm{b}} \pm 1.65$ & $7.52^{\mathrm{a}} \pm 1.42$ & $6.68^{\mathrm{b}} \pm 1.71$ & $7.10^{\mathrm{a}} \pm 1.96$ & $7.06^{\mathrm{a}} \pm 2.00$ & $7.88^{\mathrm{a}} \pm 1.53$ \\
\hline
\end{tabular}

Value are means \pm S.D mean values down the column with the same superscripts are not significantly different $(P \geq 0.05)$ 


\section{CONCLUSION}

The result from this study supports the traditional belief that potash addition increases oil yield from groundnut. Approximately $14 \%$ to $27 \%$ were recorded with $0 \%$ to $0.64 \%$ potash additions. The physical attributes showed that sample extracted with $0.64 \%$ potash had the highest refractive index value, impurities and has a lighter colour when compared to the rest of the samples indicating some negative effect of potash addition on groundnut oil quality. Potash addition also shows progressive increase in the iodine, saponification and peroxide values with increasing potash addition. This might indicate higher tendency of the oils to go rancid during storage. Kulikuli produced from groundnut cake after oil extraction with potash $(0.64 \%)$ had highest ash content presumably due to some residual amount of potash in the kulikuli. The progressive decrease in moisture and fat content of the kulikuli with increasing potash addition imply longer shelf life stability from microbial and rancidity points of view. Potash addition had no effect on the appearance of the kulikuli. Highest preference of the panelist for crunchiness and breakability of sample having the highest level of potash is suspected for its highest rating in overall acceptability.

\section{REFERENCES}

Akinhanmi, T., Atasie, V. and Akintokun, P. (2008). Chemical composition and physico-chemical properties of cashew nut (Anacardium occidentale) oil and cashew nut shell liquid. Journal of Agriculture, Food and Environment Science, 2 (1), 1-10.

Al-Bachir, M. (2015). Quality characteristics of oil extracted from gamma irradiated peanut (Arachis hypogea L.). Radiation Physics and Chemistry, 106, 56-60.

Association of Official Analytical Chemists (AOAC) (2005). Official Methods of Analysis, (18th ed.) Association of Official Analytical Chemists, Maryland, USA.

American Oil Chemists' Society (AOCS) (1993): Official Methods of Analysis, (12th ed.) American Oil Chemists' Society, Maryland, USA.

Ayoade, F. and Adegbite, T.D., (2016). Microbiological screening of streetvended groundnut cake, Kulikuli and natural spices for reducing microbial contamination in the food snack. International Journal Biology Chemical Science 10(6), 2677-2691.

Belitz, H.D., Grosch, W. and Schieberle, T.Y. (2009). Food Chemistry (4th Ed.). Berlin Heidelberg, Germany: Springer-Verlag.

Bhatti, I. A., Ashraf, S., Shahid, M., Asi, M. R. and Mehboob, S. (2010). Quality index of oils extracted from $\gamma$-irradiated peanuts (Arachis hypogaea L.) 
of the golden and bari varieties. Applied Radiation and Isotopes, 68(12), 2197-2201.

Dimic, K., Premović, T. and Takači, A. (2012). Effects of the contents of impurities and seed hulls on the quality of cold-pressed sunfl ower oil. Czech Journal of Food Science, 30, 343-350.

Emelike N. J.T. and Akusu M. O. (2018). Proximate Composition and Sensory Properties of Kuli-Kuli Produced from the Blends of Groundnut and Cashew Kernel. International Journal of Food Science and Nutrition Engineering, 8, 1-4.

Ezekiel, C.N, Anokwuru, C.P., Fari, A. Olorunfemi, M.F., Fadairo, O., Ekeh, H.A., Gbuzue, N. and Akinsanmi, F. (2011). Microbiological quality and proximate composition of peanut cake (kuli-kuli) in Nigerian markets. Academic Arena, 3(4), 103-111.

Gomathi, R., Anusuya, N., Chitravadivu, C., and Manian, S. (2011). Antioxidant activity of lettuce tree (Pisonia morindifolia R. Br.) and tamarind tree (Tamarindus indica L.) and their efficacy in peanut oil stability. Food Science and Biotechnology, 20(6), 1669-1677.

Grosso, N.R., Resurreccion, A.V.A., Walker, G.M. and Chinnan, M.S. (2008). Sensory profile and hexanal content of cracker-coated and roasted peanuts stored under different temperatures. Journal of Food Processing and preservation, 32, 1-23.

Gulluoglu L., Basal H., Onat B., Kurt C. and Arioglu H. (2016). The effect of harvesting on some agronomic and quality characteristics of peanut grown in the Mediterranean region of Turkey. Field Crops Research, 21, 224-232.

Ibrahim, A., Salaudeen, M., Bello, L., Abdullahi, A., Adamu, A. and Ayeleke, D. (2017). Growth and yield components of some groundnut (Arachis hypogaea L.) cultivars infected with blackeye cowpea mosaic virus. Agrosearch, 17(1), 11-25.

Mazaheri-Tehrani M., Yeganehzad S., Kazmkhah-sharabiani S., and Amjadi H. (2009). Physicochemical and sensory properties of peanut spreads fortified with soy flour. World Applied Sciences Journal, 7(2), 192196.

Nkafamiya, I., Maina, H., Osemeahon, S., \& Modibbo, U. (2010). Percentage oil yield and physiochemical properties of different groundnut species (Arachis hypogaea). African Journal of Food Science, 4(7), 418-421.

Opoku-Bohene, Y. O., Novick, B.D. and Wubah, D. (2013). Physicochemical characterization of traditional Ghana on cooking oils, derived from 
seeds of Egusi (Citrullus colocynth) and Werewere (Cucumeropsis manni). International Journal of Biological and Chemical Sciences, 7(1), 387-395.

Osei, K., Asibuo, J. Y., Agyeman, A., Osei-Bonsu, P., Danso, Y. and Adomako, J. (2013). Reactions of some confectionery groundnut accessions to plant parasitic nematodes infection. Agrosearch, 13(2): $1-11$

Sarwar, A., Vunguturi, S., and Ferdose, A. (2016). A study on smoke point and peroxide values of different widely used edible oils. International Journal of Engineering Technology Science and Research, 3(5), 271-273.

Shahidi, F. (2005). Bailey's industrial oil and fat products (6th ed.). New Jersey: John Wiley \& Sons. Retrieved from http://www.mrw.interscience.wiley.com/biofp

Syed, N., Mahesar, S., Sherazi, S. T. H., and Soylak, M. (2019). Quality assessment and safety measurement of different industrial processing stages of soybean oil. Turkish Journal of Food and Agriculture Sciences, 1(2), 28-33.

Singh, F. and Diwakar, B. (1993). Nutritive value and uses of pigeon pea and groundnut. International Crops Research Institute for the Semi-Arid Tropics. Skill Development Series, 14, 49-60.

Uquiche, E., Jeréz, M., \& Ortíz, J. (2008). Effect of pretreatment with microwaves on mechanical extraction yield and quality of vegetable oil from Chilean hazelnuts (Gevuina avellana Mol). Innovative Food Science and Emerging Technologies, 9(4), 495-500.

Variath, M.T, and Janila, P. (2017). Economic and Academic Importance of peanut. In: R. Varshney, M. Pandey, N. Puppala, (Eds.) The peanut genome. Compendium of plant genomes. Cham. Springer.doi:10.1007/978-3-319-63935-2_2.

Yol, E., Ustun, R., Golukcu, M., \& Uzun, B. (2017). Oil content, oil yield and fatty acid profile of groundnut germplasm in mediterranean climates. Journal of the American Oil Chemists' Society, 94(6), 787-804.

Zekeri, M. and Tijjani, I. (2013). Resource use efficiency of groundnut production in Ringim local government area of Jigawa state, Nigeria. Agrosearch, 13(2), 42-50. 